Research, part of a Special Feature on Urban Sprawl

\title{
Urban Containment Policies and the Protection of Natural Areas: The Case of Seoul's Greenbelt
}

\author{
$\underline{\text { David N. Bengston }}^{1}$ and Yeo-Chang Youn ${ }^{2}$
}

\begin{abstract}
Countries around the world have responded to the problems associated with rapid urban growth and increasingly land-consumptive development patterns by creating a wide range of policy instruments designed to manage urban growth. Of the array of growth management techniques, urban containment policies are considered by some to be a promising approach. This paper focuses on greenbelts, the most restrictive form of urban containment policy. The long-standing greenbelt of Seoul, Republic of Korea is examined as a case study. Seoul's greenbelt has generated both significant social costs and benefits. Costs include higher land and housing prices in the urban area surrounded by the greenbelt, additional costs incurred by commuters who live beyond the greenbelt and work in Seoul, and increased congestion and related quality of life impacts. Benefits include the amenity value of living near the greenbelt, recreational resources, bequest and heritage values, fiscal savings due to increased efficiency in the provision of public services and infrastructure, and a wide range of life-supporting ecosystem services. After standing virtually unchanged for almost three decades, Korea's greenbelt policy is currently being revised and weakened, largely due to pressure from greenbelt landowners and developers. Although there is no definitive answer to the question of whether Seoul would be a more or less "sustainable city" today without the greenbelt, it is certain that in the absence of the greenbelt, Seoul would have lost much of its rich natural heritage and essential ecosystem services.
\end{abstract}

Key Words: urban sprawl; urban containment; greenbelt; urban sustainability; urban planning

\section{INTRODUCTION}

Rapid urban growth and expansion of cities into natural areas is a worldwide phenomenon that poses a significant challenge to sustainability. Lowdensity or sprawling development provides a variety of private benefits to new residents, developers, and other stakeholders, as well as potential social benefits such as more affordable housing from building on cheaper land some distance from urban centers (Kahn 2001). Gordon and Richardson (1997) summarize the arguments in favor of lowdensity development.

Sprawling, land-consumptive development is increasingly recognized as a growing problem that entails a wide range of social and environmental costs. The social costs of sprawl include higher costs for provision of public infrastructure, more vehicle miles traveled, less cost-efficient transit, and a variety of negative quality of life impacts (Burchell et al. 1998). The environmental impact of urban sprawl has been well documented (Kahn 2000, Johnson 2001). For example, In the United States, sprawl is the leading cause of habitat loss and species endangerment on the mainland (Czech et al. 2000), is the most significant factor affecting forest ecosystems in the southern United States (Wear and Greis 2002), and removes significantly more prime agricultural land than more compact development (Landis 1995). Sprawling development patterns are clearly a significant obstacle to moving toward sustainable cities and sustainable development in general.

Countries around the world have responded to the growing concern about the problems associated with sprawl by creating a wide range of policy instruments, designed to manage urban growth and protect open space (Bengston et al. 2004, Richardson and Bae 2004). However, the effectiveness of these policies is often questioned. 
Innovative and effective policies will be required to stem the tide of increasingly land-consumptive development. Out of the array of growth management techniques, urban containment policies are considered by some to be a promising approach. National urban containment policies have been in place for many decades in a few countries, including the United Kingdom and the Republic of Korea. In other countries, including the United States, local urban containment programs have been created by individual municipalities without direction or assistance from state or national governments (Dawkins and Nelson 2002).

Pendall et al. (2002) distinguish three types of urban containment policies: greenbelts, urban growth boundaries, and urban service boundaries. A greenbelt refers to a physical area of open space, e. g., farmland, forest, or other greenspace, that surrounds a city or metropolitan area, and it is intended to be a permanent barrier to urban expansion. Development is strictly regulated or prohibited on greenbelt land. Greenbelts can be created through public or nonprofit acquisition of open space or development rights, as in Boulder, Colorado, USA (Pollack 1998), or they can be created and enforced by regulation of private property. Voters in Ann Arbor, Michigan, USA recently overwhelmingly approved a greenbelt proposal that will involve the purchase of both land and development rights (Ann Arbor News 2003). Greenbelts have rarely been used in the United States, but they have been used much more extensively in large cities throughout Europe and Asia. London was the first major city to introduce a greenbelt system in the late 1930s (Munton 1983). Other cities that have adopted, or adopted and subsequently abandoned, greenbelts include Ottawa, Ontario and three other Canadian cities (Taylor et al. 1995), Asian megacities including Tokyo, Seoul, and Bangkok (Yokohari et al. 2000), and many large European cities such as Berlin, Vienna, Barcelona, and Budapest (Kuhn 2003).

In contrast to greenbelts, an urban growth boundary (UGB) is not a physical space, but a dividing line drawn around an urban area to separate it from surrounding rural areas. Zoning and other regulatory tools are used to implement an UGB. Areas outside the boundary are zoned for rural use, and the area inside is zoned for urban use. A key distinction between UGBs and greenbelts is that the former are not intended to be permanent. An UGB is typically drawn to accommodate expected growth over time, and the boundary is reassessed and expanded as needed. In Oregon, USA, the Land Conservation and Development Act of 1973 requires, among other things, the delineation of urban growth boundaries around all of the state's cities and around the entire Portland metropolitan area (Nelson 1994).

Urban service boundaries, the third type of urban containment policy, are even more flexible than UGBs. An urban service boundary delineates the area beyond which certain urban services such as sewer and water will not be provided. They are often linked with adequate public facilities ordinances that prohibit development in areas not served by specific public services and facilities. In general, urban service boundaries have had limited success in containing sprawl, because they tend to be easily and frequently amended in the face of political pressure to accommodate growth, and because they tend to not be accompanied by regulations, aimed at limiting development beyond the urban service boundary (e.g., Dearborn and Gygi 1993, Poradek 1997).

This paper focuses on greenbelts, the most restrictive form of urban containment policy. The idea of surrounding cities with a belt of agricultural land or other open space is an ancient one, dating back at least to the 13th century B.C. and the Levitical cities of Palestine (Ginsburg 1956, Osborn 1969). In more recent times, greenbelts were proposed in the influential work of Sir Ebenezer Howard in 1898 (Howard 1902), and they have been a widely used policy instrument in some countries for containing urban expansion, protecting agricultural land and open spaces, and achieving other public goals. Greenbelts have long been a controversial public policy instrument because of their purported negative consequences, including increased land and housing prices in the urban area contained by the greenbelt, decreased greenbelt land prices, loss or restriction of development rights for greenbelt landowners, increased urban congestion, and other undesirable consequences. In some cases, greenbelts have been blamed for increased sprawl and higher commuting costs as development goes beyond the greenbelt. However, greenbelts also generate significant social and environmental benefits, including amenity and recreational value, bequest value, and protection of open space, agricultural land, natural resources, and lifesupporting ecosystem services. 
In this paper, we examine the long-standing greenbelt surrounding Seoul, Republic of Korea. As discussed below, Seoul's greenbelt has generated both significant social costs and benefits. Some have suggested that, overall, Seoul's greenbelt is a rare success in urban containment: "The greenbelt in Seoul, so far, may be evaluated as one of few successful greenbelt experiences in Asia," (Yokohari et al. 2000:163). Others claim that the social costs of Seoul's greenbelt have overwhelmed the benefits and that the policy should be abandoned. The debate about Seoul's greenbelt policy is part of a broader debate among urban planners about the desirability and sustainability of compact cities (e. g., Jenks et al. 1996, Gordon and Richardson 1997).

Important questions to ask regarding Seoul's greenbelt include the following: Has the greenbelt been effective at containing urban growth? Has this policy helped promote more sustainable development and protect environmentally sensitive areas, agricultural lands, and open space? What are the social costs and benefits of Seoul's greenbelt policy? Have the benefits outweighed the costs? The following sections describe the context and history of Seoul's greenbelt, summarize studies of its costs and benefits, and discuss recent major reforms in policy. A concluding section discusses lessons from the Korean experience and relevance for growth management and urban sustainability in other countries.

\section{SEOUL'S GREENBELT POLICY}

\section{Social and economic context: rapid growth and urbanization}

In 1970, just prior to the establishment of Seoul's greenbelt policy, a prominent urban planner observed "Nowhere else in the world today are the processes of urbanization so intense, so compressed in time, as in the capital of South Korea," (Meier 1970:384). The rate of growth in the Korean economy was the second highest in the world from 1965-99 after Botswana (Song 2003). Koreans transformed their economy from an impoverished and war-torn agrarian economy following the Korean War to a modern industrial power in only a few decades. By 2003, South Korea was ranked 11th in total Gross Domestic Product (GDP) among the world's nations (World Bank 2004).
Rapid population growth and rural-urban migration have accompanied Korea's rapid economic growth. Seoul grew more rapidly than any city in the world from 1950-1975, growing at an average annual rate of $7.6 \%$ (UNPD 2002). Seoul's population grew from just over $1 \times 10^{6}$ in 1950 to more than $6.8 \mathrm{X}$ $10^{6}$ in 1975. By 2000, the population of Seoul was about $10 \times 10^{6}$ million, but the population of the entire Capital Region of Gyeonggi Province, including the city of Inchon, had ballooned to more than $21 \times 10^{6}$.

\section{Response to rapid urban growth}

Korea's greenbelt system was introduced in 1971 during the authoritarian government of President Park Chung Hee. It was patterned after the greenbelt of London (Bae 1998), but it has also been adapted in the Korean context. Greenbelts, formally referred to as restricted development zones (RDZs) in Korea, were introduced in the City Planning Law of 1971, and shaped by the 1972-1981 National Comprehensive Physical Plan of 1973 (Lee 2004). Greenbelts were designated around Seoul and 13 other cities between 1971 and 1973.

Seoul's greenbelt is very large, consisting of a band averaging about $10 \mathrm{~km}$ wide, beginning about 15 $\mathrm{km}$ from Seoul's central business district (Fig. 1). After being extended four times, by 1976 Seoul's greenbelt was $\sim 1,566.8 \mathrm{~km}^{2}$, which amounts to $13.3 \%$ of the entire Seoul Metropolitan Area. However, the population that lives within the greenbelt is small, accounting for only $1.66 \%$ of the Seoul Metropolitan Area's population (Bae and Jun 2003). Most development was strictly prohibited on greenbelt land, and greenbelt landowners have not been compensated for their loss of development rights (Bae 1998, Lee 1999). The economic hardship, imposed on landowners, has been contentious from the beginning, because nationwide, approximately $80 \%$ of the land within the greenbelts is privately owned (Lee 2004). The boundaries of Korea's greenbelts were hastily drawn without public input, and without serious consideration of the widely accepted criteria for the designation of greenbelts. In one case, a village was divided down the middle by the greenbelt boundary (Choe 2004b). 
Fig. 1. Map of Gyeonggi Province and Seoul's greenbelt.

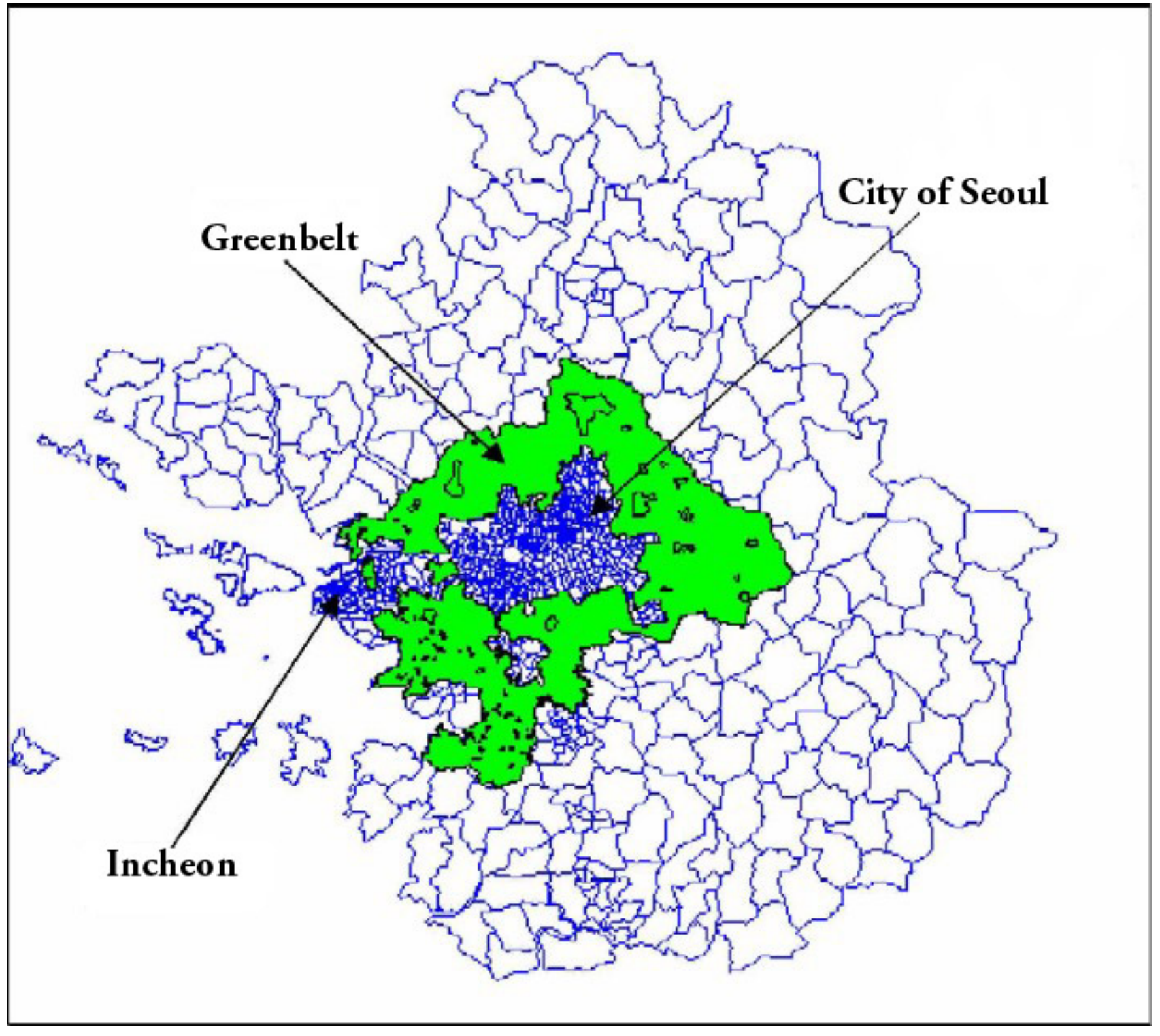

Bae (1998) identified seven objectives for the establishment of Seoul's greenbelt. First, unlike greenbelts in most countries, national security was originally a dominant objective. Given the perceived threat of invasion from North Korea, the greenbelt allowed the government to strictly control development near the demilitarized zone north of Seoul. Choe (2004a) notes that more than $40 \%$ of
South Korea's population was living within range of a ground artillery attack from North Korea in the early 1970s. Second, greenbelt regulations were used as a means to eradicate illegal shantytowns on the outskirts of Seoul. Third, the greenbelt was viewed as a way to control urban sprawl. Government efforts to control the rapid expansion of Seoul during the 1960s had been ineffective (Kim 
and Kim 2000). A fourth objective was to reduce rapid population growth and industrial concentration in the Capital Region. Fifth, expansion of the greenbelt was viewed as a way to limit land speculation in the metropolitan region. Sixth, the greenbelt was intended to protect agricultural land and promote food security. Finally, environmental and natural resource protection was also an objective of the greenbelt policy.

The relative importance of these objectives has changed over time. For example, the importance of environmental protection as a rationale for the greenbelt has grown significantly over time as environmental awareness and economic prosperity in Korea have increased (Lee 2004). An additional and increasingly important rationale for Seoul's greenbelt is the provision of recreational resources to a city with a shortage of parks and open space. Almost $60 \%$ of Seoul's greenbelt consists of mountains and forests that are heavily used for recreation (Bae and Jun 2003). Figure 2 depicts the extremely heavy recreational use of the many hiking paths in Seoul's greenbelt on a typical weekend.

Korea's greenbelt policy has enjoyed high levels of support from the general public (Kim and Kim 2000). Lee (1999) cites several surveys conducted in the 1990s that drew strong support from citizens, environmentalists and Korean planners, but most greenbelt property owners who viewed it as a seizure of private property, opposed the policy. A 1998 survey, conducted by the Ministry of Construction and Transportation (MOCT), found that most government officials and academics preferred to retain the greenbelt, but they felt that reforms were needed to ensure that development goals were achieved (MOCT 1998). Lee (2004) carried out a multivariate analysis of the 1998 MOCT national survey data to account for variation in greenbelt support. He found greater support for the greenbelt policy from individuals with higher incomes and educational attainment, and lower support from individuals residing in regions with strong development pressure, and in the Capital Region. Surprisingly, he did not find a statistically significant relationship between opposition to the policy and landownership within greenbelt boundaries.

\section{ECONOMICS OF THE GREENBELT: COSTS AND BENEFITS}

\section{Costs of Seoul's greenbelt}

Most of the economic studies of Seoul's greenbelt have focused on its social costs, especially higher land prices, housing prices, and commuting costs. For example, an early econometric study by Kim et al. (1986) estimated the decrease in housing prices as a result of a relaxation of the greenbelt's inner edge. They estimated that a $1 \mathrm{~km}$ outward movement of the inner edge of the greenbelt, which would add about $14 \%$ to Seoul's developable land, would reduce housing prices inbound of Seoul, a subset of the City of Seoul, by $2.7 \%$. This modest reduction in housing prices was due, in part, to the relatively elastic demand for housing.

Choi (1994) analyzed the effect of Seoul's greenbelt on land prices, while controlling for other variables. He estimated that the land prices in the greenbelt, in 1987 , were about $30 \%$ below the land values outside the greenbelt, a much smaller price differential than has been suggested by anecdotal reports. Choi's analysis also indicated that if Seoul's greenbelt had been eliminated in 1987, greenbelt land prices would have risen by an average of $32.1 \%$, and those of land outside the greenbelt would have fallen by $7.5 \%$. If the price effect was only felt inside the greenbelt, an unrealistic assumption, then the reduction in the price of land was estimated at approximately $19.2 \%$.

In a simulation, Kim (1993) tested the effect of a $1 \%$ increase in residential land supply on housing prices, achieved by releasing about $1.2 \%$ of greenbelt land. He found that the estimated effects varied with parameter values. For example, if the elasticities of housing supply and demand prices were 1.0 and 0.5 , respectively, then by relaxing the greenbelt $1.2 \%$, land and housing prices would decrease by 1.4 and $0.2 \%$, respectively. Additional studies include Son and Kim (1998) who found that greenbelts, rather than natural constraints such as mountains, are the main cause of urban land shortages in Korea. However, Hannah et al. (1993) concluded that the government's tendency to under allocate land to urban residential use was responsible for a substantial part of increased urban housing prices.

It is important to recognize that Seoul's greenbelt policy is but one of many supply-side restrictions 
Fig. 2. Heavy recreational use of hiking paths in Seoul's greenbelt. (Photo: Chris Murphy).

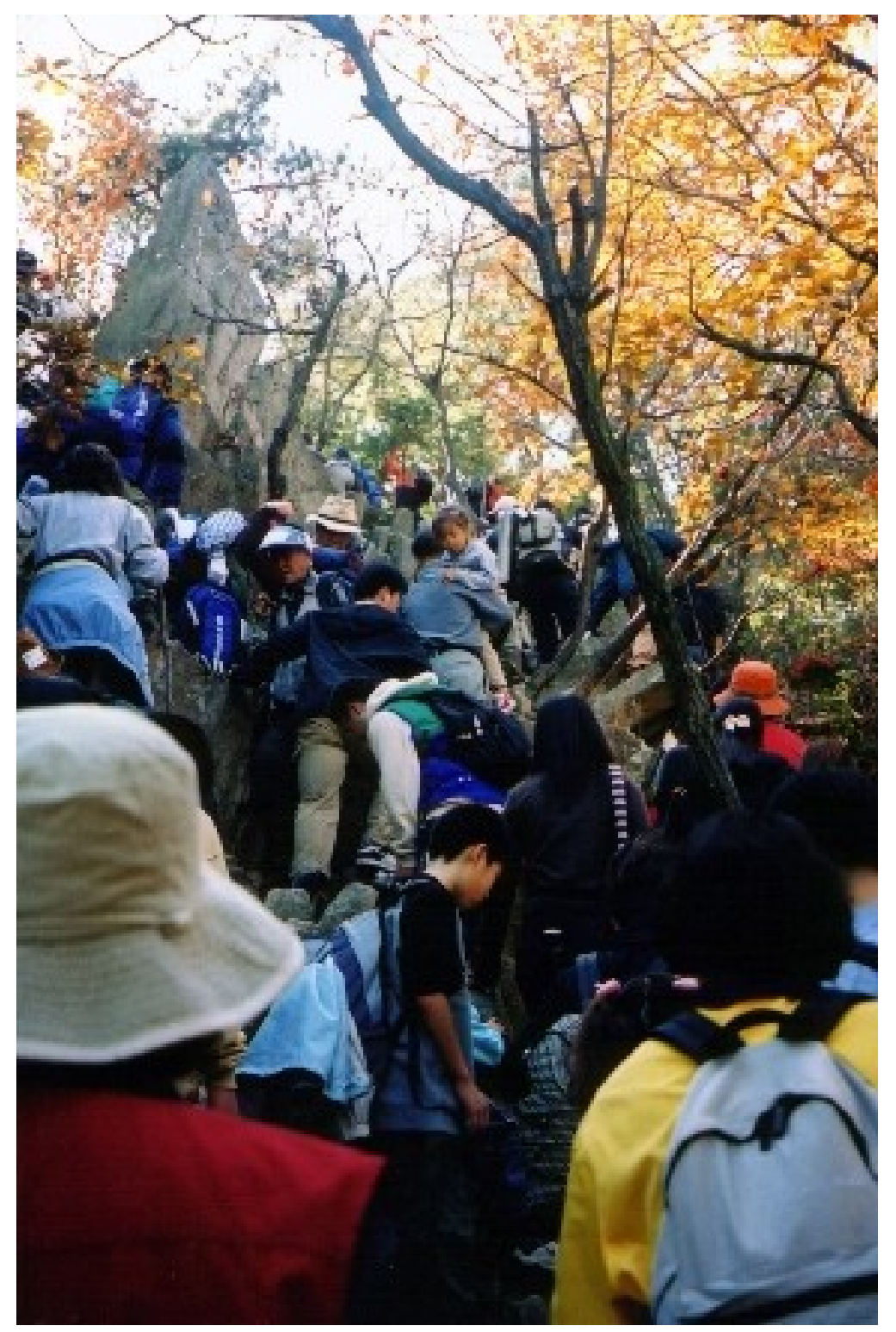

that put upward pressure on land and housing prices. A variety of other government policies could restrict land and housing supply, including multiple layers of urban and agricultural zoning, a virtual public monopoly on urban land development, the system of land and housing taxation, and an inadequate system of housing finance (Kim 1990, Choi 1993, Kim 1993). Demand-side factors such as the local and regional amenities provided by greenbelts, also put upward pressure on land and housing prices by shifting the demand curves for land and housing outward. In the econometric analyses summarized in the preceding paragraphs, the price differentials between land, i.e., both inside and outside the greenbelt, and housing should be due only to supply constraints caused by the greenbelt, and not to other factors affecting supply and demand. 
Several studies have examined the additional costs incurred by commuters who live beyond the greenbelt and work in Seoul. For example, Han (1997) estimated the social costs associated with Seoul's greenbelt, and found that increased travel costs were the largest component. Additional travel costs, excluding the value of commuting time, were estimated at U.S. \$192, i.e., 250,000 won/person/ $\mathrm{yr}$, or a total of U.S. $\$ 3.6 \times 10^{9}$, i.e., $470 \times 10^{9}$ won/yr. A lower estimate of the additional travel costs, including the value of commuting time, was about $365 \times 10^{9}$ won/yr, in the late 1980s (Kim 1993). See Jun and Bae (2000) and Jun and Hur (2001) for additional estimates of commuting costs associated with Seoul's greenbelt. Cho (1997) developed a theoretical model that demonstrates the congestion costs of a binding greenbelt, and he applied this model to Seoul's greenbelt. This model suggests that the marginal costs of the congestion may have begun to exceed the marginal benefits, $i$. e., the locational advantages of living in the city. There is some evidence that greenbelts in the United Kingdom have also resulted in longer commutes and higher commuting costs (Evans 1998).

\section{Benefits of Seoul's greenbelt}

None of the above studies have considered the economic benefits of Seoul's greenbelt. In general, greenbelts may provide three main categories of benefits: (1) amenity value related to scenic beauty, recreational opportunities, and bequest/heritage values; (2) fiscal savings due to increased efficiency in the provision of public services and infrastructure associated with more compact development, and perhaps most significantly; (3) a wide range of ecosystem services such as air purification, habitat and biodiversity protection, flood control, water supply and quality, and many others. The few studies that have examined the benefits of Seoul's greenbelt have looked only at part of the first benefit category and have neglected the other two categories.

Strong evidence suggests that greenbelts generate an amenity value to nearby urban land (e.g., Correll et al. 1978, Nelson 1986, 1988, Knaap and Nelson 1988), and a large body of literature documents the significant impact of open space on residential property values (see Fausold and Lilieholm 1996, and studies cited therein). A few studies have explored the amenity benefits of Seoul's greenbelt. For example, an econometric analysis by Lee and Linneman (1998) found significant amenity value, although the benefits began to decrease after 1980 due to the effect of congestion. Lee and Fujita (1997) demonstrate theoretically that, depending upon the nature of the greenbelt amenity, there are circumstances in which residential development, extending beyond a greenbelt could be economically efficient, i.e., when the social benefits of the greenbelt outweigh its social costs. In this example, the amenity value was of benefit to residents living both inside and outside of the greenbelt. In another study that explored the amenity benefits of Seoul's greenbelt, Bae et al. (2003) found that the proximity to the greenbelt was a much more important determinant of residential property value than the proximity to a new subway line.

The bequest and heritage values of Seoul's greenbelt and the desire of many citizens to pass on this natural heritage to future generations are likely to be significant (Jin and Park 2000), but they have not been studied. Seoul's greenbelt has an ancient historical precedent: The first king of the Choson Dynasty (1392-1910) prohibited all types of land use and development in the mountains around Seoul by Royal Proclamation in 1397 (Han 1992). The main reason for protecting the mountainous areas around the ancient capital was to protect the natural environment for spiritual purposes, based on the belief in the principles of feng shui. In addition, village groves have an ancient history in traditional Korean village life (Park and Lee 2002). For many centuries, these groves have had a great spiritual, social, and ecological significance. Village groves served as small-scale greenbelts, separating villages from agricultural fields and preventing the encroachment of villages into farmland. Thus, the current greenbelt system is linked to Korea's history and deeply-held cultural values.

The fiscal savings attributable to Seoul's greenbelt, due to increased efficiency in the provision of public infrastructure such as roads, water and sewer systems, and schools, have not been estimated, although these may be significant sources of benefits. Although not universal, there is agreement in the empirical literature on the costs of urban sprawl that development density is linked to infrastructure costs, with lower costs associated with higher development density (Burchell et al. 1998, 2002). Seoul is among the most densely populated cities in the world, in part because of its greenbelt, and hence, the fiscal savings may be substantial. 
Finally, although the ecosystem service benefits of Seoul's greenbelt have not been analyzed, an abundance of other literature suggests the importance, and perhaps the primacy, of this category of benefits. Yokohari et al. (1994) identified 26 ecological functions of farmland and forests that provide benefits to urban areas, all of which are relevant for greenbelts. For example, the main function of Bangkok's greenbelt, or green zones, is to control flooding of the Chao Phraya River (Yokohari et al. 2000), and paddy fields in urban fringe areas have been found to have a significant effect on controlling summer heat in surrounding residential areas (Yokohari et al. 1997; see also Koh et al. 1999). Greenbelts of various types have also been recognized as both an important habitat for endangered species (Mortberg and Wallentinus 2000) and a source of air pollution abatement (Khan and Abbasi 2000a,b). The wellknown case of the New York City watershed (Daily and Ellison 2002) suggests that greenbelts provide a substantial economic value by improving water quality and quantity.

Although the economic value of the ecosystem services provided by Seoul's greenbelt is unknown, it is likely to be sizeable. Recent studies suggest that when the full range of ecosystem service values are taken into account, they often dwarf other types of benefits (e.g., Costanza et al. 1997, Millennium Ecosystem Assessment 2005). In addition, the value of greenbelt ecosystem services will likely increase in the future as the population and urbanization continue to grow, and as natural systems are increasingly affected by human activities.

Only two studies have examined the net benefits of Seoul's greenbelt. Lee (1999) estimated the net social gain arising from a marginal release of greenbelt land for development. He calculated net benefits in 1975, 1980, 1984, and 1989. Although his analysis required many simplifying assumptions, and did not include important benefit categories, it does shed light on how the economic effects of a greenbelt can change over time, as the metropolitan area grows, and how the impacts of an increasingly restricted land supply and growing congestion are felt. Lee found that Seoul's greenbelt policy was inefficient in 1975, i.e., the benefits of a marginal release of greenbelt land outweighed the costs, was efficient in 1980 and 1984, as amenity benefits increased significantly, and became inefficient again in 1989, as continuing urban growth created congestion costs that overwhelmed the amenity benefits. He concluded that a fixed greenbelt, during a period of rapid urban growth, could not provide net benefits indefinitely, i.e., "... a greenbelt is just a congestible local public good," (Lee 1999:49). Kwon (1995) carried out an analysis, similar to Lee's, in which net social gains increased following the release of greenbelt land between 1975-1989. Neither Lee (1999) nor Kwon (1995) considered the benefits associated with greenbelt recreation, greater efficiency in providing public infrastructure, or the provision of ecosystem services. These benefits are likely to increase with continued urban growth.

\section{GREENBELT POLICY REFORM}

South Korea's greenbelt policy has remained essentially unchanged for almost $30 \mathrm{yr}$. Public discussion of the problems associated with the greenbelt was prohibited during the Park regime (Lee and Linneman 1998), which lasted until 1979. Subsequent military governments adhered to the greenbelt policy. Hence, expressions of opposition to the greenbelt policy were rarely heard in its early years. However, opposition from the greenbelt landowners was voiced after the current civilian republic was established in 1988 (Park 2001). During the presidential election of 1997, opposition party candidate Kim Dae Jung made a campaign promise to review and reform the greenbelt policy (Choe 2004a). After winning the election, the National Committee for Green Belt Policy Reform was established in early 1998. The Committee, chaired by Professor Choe Sang-Cheol of Seoul National University, consisted of three greenbelt residents, one environmental group representative, twelve scholars, three government officials, and three journalists (Park 2001).

After an arduous, yearlong process of meetings and deliberations, the Committee submitted a draft report to the Ministry of Construction and Transportation (MOCT) on 24 November 1998 (Choe 2004a). The report recommended the following reforms: (1) The greenbelt policy should be maintained as a growth management tool, but greenbelt zones should be lifted around small- and medium-sized cities that have little development pressure, and they should be replaced by conventional zoning regulations; (2) In large cities that retain greenbelts, the boundaries should be redelineated, based on environmental assessments and other local factors; (3) A scheme to recoup 
windfall benefits due to abolishing or relaxing greenbelts should be introduced to prevent land speculation; (4) In areas that are to remain greenbelts, landowners should be compensated for their loss of development rights, or offered the option of having their land purchased by the government at a fair price; and (5) Villages above a certain size, within greenbelts, should be given special permission for developments needed to improve their communities.

Release of the draft report generated conflict. On the same day that the report was issued, a group entitled National Action for Greenbelt (NAG) was established (Park 2001). NAG supported the preservation of the greenbelt and used a diversity of tactics in attempts to derail reform. For example, NAG investigated the MOCT committee of the National Assembly to find out whether any of the members owned greenbelt land; indeed, six of the thirty members were landowners. The NAG also used the press effectively to gain public support for preserving the greenbelts.

In late November and early December of 1998, the MOCT held a series of public hearings in greenbelt cities across Korea to discuss the draft report. Greenbelt residents who were unhappy that the report did not recommend the complete removal of Seoul's greenbelt disrupted the public hearing held in Seoul. In response to the growing conflict, the MOCT requested a commentary on the draft report from the British Town and Country Planning Association (TCPA) on 12 December 1998. Founded in 1899 to promote Ebenezer Howard's Garden City concept, the TCPA is Britain's oldest nongovernmental organization that is concerned with planning and the environment. The TCPA commentary, released on 3 June 1999 (see Town and Country Planning Association 1999ab),

generated divergent views about whether it supported the reforms that were recommended by the National Committee for Green Belt Policy Reform (Park 2001).

While conflict among greenbelt stakeholders raged, a committee of delegates from the MOCT, the Korea Research Institute for Human Settlements, and other research institutes was established to work out practical and legal details of greenbelt reform (Choe $2004 a$ ). However, because they were unable to reach an agreement among stakeholders, the MOCT unilaterally announced a new RDZ policy on 22 July 1999. The committee recommended that greenbelts be eliminated around seven small- and mediumsized cities, and that the land be rezoned as either conservation- or natural-green areas, using the zoning categories from Korea's City Planning Law. Greenbelts in the seven larger cities were to be maintained, but redrawn based on environmental assessments that included factors such as topography, land suitability, ecological sensitivity, and environmental vulnerability (Choe 2004a).

Redrawing of the greenbelt boundaries was to be accomplished using metropolitan area-wide planning, but an agreement between the many municipal governments in the Capital Region proved to be contentious. An effort to develop a metropolitan area plan for the Capital Region began in 2002, but it is not likely to be completed until 2005 or 2006 (S. C. Choe 2004, personal communication). In the meantime, $112.5 \mathrm{~km}^{2}$ of Seoul's greenbelt has been proposed to be released; the land is to be made available for development according to the 15-yr metropolitan plan, rather than all at once (Bae and Jun 2003).

Opposition to the release of land from Seoul's greenbelt from environmental groups and many residents of Seoul has continued in recent years, as proposals for development have moved forward. This is reflected in news media discussions about greenbelt reform. For example, an editorial discussing a plan by the Seoul Metropolitan Government to construct 100,000 apartment units on land currently in the greenbelt mentioned the protests that have taken place and stated "... city hall and the central government should have first considered the unavoidable damage that will be done to the greenbelt, which acts as the lungs of the city. Needless to say, if the greenbelt turns into a forest of apartments under the development project, the overpopulation of the capital city will certainly worsen, while residents will also lose the small amount of natural environment that still exists," (Korea Times 2003). An editorial in another newspaper stated "... Seoul's green belt has been protected so far, because there are more merits than demerits in maintaining it. We have to continue to be careful about damaging it. Destruction of nature for housing development and subsequent traffic congestion is not a net gain in our welfare," (JoongAng Daily 2003). 


\section{CONCLUSIONS}

Drawing on the work of Hall et al. (1973), Bruegmann (2005:16,090) characterizes the effectiveness and effects of London's greenbelt system, the main inspiration for Seoul's greenbelt, as follows: "This system... did in fact stop much, although not all, of the growth that otherwise might have invaded the greenbelt around London. It was not nearly as successful in containing growth beyond the belt. In fact, growth beyond the greenbelt eventually scattered across much of southeast England."

This statement could very well have been written about Seoul's greenbelt, except that Seoul's strictly enforced policy has been much more effective at keeping development, other than agricultural use, out of the greenbelt. However, Seoul's urban containment policy has largely failed to keep development from invading the Capital Region beyond the greenbelt. The intense pressure of exceptionally rapid urban growth has simply been too much to contain. As a result, the area of land occupied by the entire metropolitan region is probably larger than it would have been in the absence of the greenbelt (Bae and Jun 2003). However, Seoul's greenbelt has been remarkably successful at protecting important agricultural land, providing badly needed recreational resources in a megacity with few parks, protecting the beauty and natural heritage of the ancient capital of Korea, and maintaining vital ecosystem services.

The equity impact of Seoul's greenbelt policy, i.e., who pays and who benefits, is an important but neglected area of research. The two main equity concerns have been the uncompensated loss of development rights in the greenbelt area and the effect of the greenbelt on housing affordability in Seoul. With respect to the first concern, greenbelt landowners have clearly borne a significant cost because of the policy. The main impetus for greenbelt reform in Korea has been the rights of landowners and their demand for compensation (Jin 2001). In a landmark case, the Constitutional Court ruled in 1998 that the government must pay compensation to those who lost development rights (Cho 2002). One of the major objectives of the ongoing greenbelt reform effort is to fairly redistribute property rights in greenbelt areas among those who are affected (Kim 2004).
The effect of the greenbelt on housing affordability is also a prominent equity concern, given the widespread perception that growth controls inevitably result in much more expensive housing. A comparative international study on the effect of urban containment policies on housing prices concluded that urban containment programs do affect land prices, but that the "demand side of the housing market may be a stronger determinant of prices than local urban containment policies" (Dawkins and Nelson 2002:1). The cost studies reviewed in this paper suggest that the effect of Seoul's greenbelt on land and housing prices has been relatively modest. This is consistent with recent analyses of the strong urban growth boundary of Portland, Oregon, USA (Phillips and Goodstein 2000, Downs 2002). However, to the extent that the greenbelt, and not other factors, is responsible for higher housing prices, this suggests the need for progressive housing policies to ensure adequate supplies of affordable housing.

A lesson of this review is that urban containment policies have led to both significant costs and benefits, and that these change over time with population and economic growth. A number of researchers have concluded that the social costs of Seoul's policy could have been reduced if the greenbelt had been more flexible and accommodated growth, similar to most urban growth boundaries in the USA. For example, in discussing the implications of Seoul's policy, Dawkins and Nelson (2002:6-7) state “... urban containment boundaries should be periodically reevaluated and extended to allow for sufficient land release. If the boundary is not periodically revised, net social benefits will be offset by the increased social costs associated with congestion externalities and land supply constraints," (see also Lee 1999:50, Jun and Hur 2001:158). This view represents the conventional wisdom of the urban planning profession: growth accommodation is always the preferred policy (Zovanyi 1998).

However, this view fails to account for what are likely the most significant categories of benefits associated with Seoul's greenbelt: the life supporting ecosystem services and the recreational resources it provides to residents of the Seoul Metropolitan Area. The value of these benefits will likely be substantial, and will rise with continued growth and urbanization. Therefore, although few studies have empirically examined the benefits of Seoul's greenbelt policy, and no studies have 
attempted to measure the economic value of its ecosystem services, recreational resources, or bequest and heritage values, it seems likely that the greenbelt has provided net benefits to society when the full complement of benefits are taken into account.

Would Seoul be a more or less sustainable city today without the greenbelt? There is no definitive answer to this question. Despite the importance of moving toward more sustainable cities in our increasingly urbanized world, there is no consensus about the nature or dimensions of urban sustainability (Burton et al. 1996). Assessing urban sustainability is an extraordinarily complex task because of the complexity of cities: they consist of many layers of constantly changing economic, social, legal, cultural, political, and ecological systems. However, we do know with certainty that in the absence of the greenbelt, Seoul would have lost much of its rich natural heritage and essential ecosystem services.

Responses to this article can be read online at:

http://www.ecologyandsociety.org/voll1/iss 1/art3/responses/

\section{Acknowledgments:}

The authors are grateful to the Organisation for Economic Co-operation and Development (OECD) Co-operative Research Programme, Biological Resource Management for Sustainable Agricultural Systems, for providing a fellowship that enabled Bengston to participate in this study. They thank Prof. Choe Sang-Chuel of Seoul National University for his insights into the recent efforts to reform Korea's greenbelt policy, and they thank Professors Casey Dawkins, Kai Lee, and Edward Goetz for helpful comments on an earlier version of this paper.

\section{LITERATURE CITED}

Ann Arbor News. 2003. Greenbelt proposal wins landslide voter approval. The Ann Arbor News $\quad(5$ Novermber 2004): 1A. Ann Arbor, Michigan, USA.

Bae, C. 1998. Korea's greenbelts: impacts and options for change. Pacific Rim Law and Policy Journal 7(3):479-502.

Bae, C., and M. J. Jun. 2003. Counterfactual planning: what if there had been no greenbelt in Seoul? Journal of Planning Education and Research 22(4):374-383.

Bae, C., M. J. Jun, and H. Park. 2003. The impact of Seoul's Subway Line 5 on residential property values. Transport Policy 10(2):85-94.

Bengston, D. N., J. Fletcher, and K. Nelson.

2004. Public policies for managing urban growth and protecting open space: policy instruments and lessons learned in the United States. Landscape and Urban Planning 69:271-286.

Bruegmann, R. 2001. Urban sprawl. Pages 16087-16092 in N. J. Smelser and P. B. Baltes, editors. International encyclopedia of the social and behavioral sciences, Volume 24, First Edition. Elsevier, New York, New York, USA.

Burchell, R. W., G. Lowenstein, W. R. Dolphin, C. C. Galley, A. Downs, S. Seskin, K. G. Still, and T. Moore. 2002. Costs of sprawl-2000. Transit Cooperative Research Program Report 74, Transportation Research Board, National Research Council. National Academy Press, Washington, D. C., USA. [online] URL: www4.trb.org/trb/crp.nsf/All+ Projects/TCRP+H-10.

Burchell, R. W., N. A. Shad, D. Listokin, H. Phillips, A. Downs, S. Seskin, J. Davis, T. Moore, D. Helton, and M. Gall. 1998. The costs of sprawl-revisited. Report 39. Transit Cooperative Research Program, Transportation Research Board, National Research Council. National Academy Press, Washington, D.C., USA. [online] URL: ww w4.trb.org/trb/crp.nsf/All+Projects/TCRP+H-10.

Burton, E., K. Williams, and M. Jenks. 1996. The compact city and urban sustainability: conflicts and complexities. Pages 231-247 in M. Jenks, E. Burton, and K. Williams, editors. The compact city: a sustainable urban form? Chapman and Hall, London, UK.

Cho, C. J. 2002. The Korean growth-management programs: Issues, problems, and possible reforms. Land Use Policy 19:13-27.

Cho, M. 1997. Congestion effects of spatial growth 
restrictions: a model and empirical analysis. Real Estate Economics 25(3):409-438.

Choe, S. C. 2004a. Reform of planning controls for an urban-rural continuum in Korea. Pages 253-266 in A. Sorensen, P. J. Marcotullio, and J. Grant, editors. Towards sustainable cities: East Asian, North American, and European perspectives on managing urban regions. Ashgate, Burlington, Vermont, USA.

Choe, S. C. 2004b. The thirty-year's experiment with British greenbelt policy in Korea: a convergent path to sustainable development. Pages 83-90 in

H. W. Richardson and C. Bae, editors. Urban sprawl in Western Europe and the United States. Ashgate, Burlington, Vermont, USA.

Choi, M. J. 1993. Spatial and temporal variations in land values: a descriptive and behavioral analysis of the Seoul Metropolitan Area (1956-1989). Dissertation. Harvard University, Cambridge, Massachusetts, USA.

Choi, M. J. 1994. An empirical analysis of the impacts of greenbelt on land prices in the Seoul Metropolitan Area. Korean Journal of Urban Planning 29(2):97-111.

Correll, M. R., J. H. Lillydahl, and L. D. Singell. 1978. The effects of greenbelts on residential property values: some findings on the political economy of open space. Land Economics 54:207-217.

Costanza, R., R. d'Arge, R. S. de Groot, S. Farber, M. Grasso, and B. Hannon. 1997. The value of the world's ecosystem services and natural capital. Nature 387:253-260.

Czech, B., P. R. Krausman, and P. K. Devers. 2000. Economic associations among causes of species endangerment in the United States.

BioScience 50:593-601.

Daily, G. C., and K. Ellison. 2002. The new economy of nature: the quest to make conservation profitable. Island Press/Shearwater Books, Washington, D.C., USA.

Dawkins, C. J., and A. C. Nelson. 2002. Urban containment policies and housing prices: an international comparison with implications for future research. Land Use Policy 19:1-12.
Dearborn, K. W., and A. M. Gygi. 1993. Planner's panacea or Pandora's box: a realistic assessment of the role of urban growth areas in achieving growth management goals. Puget Sound Law Review 16:975-1023.

Downs, A. 2002. Have housing prices risen faster in Portland than elsewhere? Housing Policy Debate 13(1):7-31.

Evans, A. W. 1998. Dr. Pangloss finds his profession: sustainability, transport, and land use planning in Britain. Journal of Planning Education and Research 18:137-144.

Fausold, C. J., and R. J. Lilieholm. 1996. The economic value of open space: a review and synthesis. Working Paper WP96CF1, Lincoln Institute of Land Policy, Cambridge, Massachusetts, USA.

Ginsburg, L. 1956. Green belts in the Bible. Journal of the Town Planning Institute 42:129-130.

Gordon, P., and H. W. Richardson. 1997. Are compact cities a desirable planning goal? Journal of the American Planning Association 63 (1):95-106.

Hall, P. H., H. Gracey, R. Drewett, and R. Thomas. 1973. The containment of urban England. Allen and Unwin, London, UK.

Han, D. W. 1992. The location and functions of Keumsan in Seoul of the early Choson Dynasty. Thesis. Seoul National University, Seoul, Republic of Korea.

Han, S. 1997. Measuring the social cost of green belt zoning. Research Report 1997-03-19, Korea Economic Research Institute, Seoul, Republic of Korea.

Hannah, L., K. H. Kim, and E. S. Mills. 1993. Land use controls and housing prices in Korea. Urban Studies 30(1):147-156.

Howard, E. 1902. Garden cities of to-morrow. Sonnenschein, London, UK.

Jenks, M., E. Burton, and K. Williams, editors. 1996. The compact city: a sustainable urban form? Chapman and Hall, London, UK. 
Jin, Y. H. 2001. Greenbelt zone regulations are relaxed across the country. Space and

Environment 16:1-4. [online] URL: http://library.kr ihs.re.kr/file/publication/att file/publication4/S\&E 16. pdf

Jin, Y. H., and J. G. Park. 2000. The reform of green belt policy: Korean experiences. Pages 125-139 in Papers and Proceedings of the International Workshop on Urban Growth Management Policies of Korea, Japan, and the USA. Korean Regional Science Association and the Korea Research Institute for Human Settlements, Seoul National University, Seoul, Republic of Korea.

Johnson, M. P. 2001. Environmental impacts of urban sprawl: a survey of the literature and proposed research agenda. Environment and Planning $A$ 33:717-735.

JoongAng Daily. 2003. Green belt erosion (editorial). JoongAng Daily [online] URL: http://jo ongangdaily.joins.com/200312/29/2003122922384 $\underline{80909900090109011 . h t m l / .}$

Jun, M. J., and C. Bae. 2000. Estimating the commuting costs of Seoul's greenbelt. International Regional Science Review 23(3):300-315.

Jun, M. J., and J. W. Hur. 2001. Commuting costs of "leap-frog" new town development in Seoul. Cities 18(3):151-158.

Kahn, F. I., and S. A. Abbasi. 2000a. Attenuation of gaseous pollutants by greenbelts. Environmental Monitoring and Assessment 64:457-475.

Kahn, F. I., and S. A. Abbasi. 2000b. Cushioning the impact of toxic release from runaway industrial accidents with greenbelts. Journal of Loss Prevention in the Process Industries 13(2):109-124.

Kahn, M. E. 2000. The environmental impact of suburbanization. Journal of Policy Analysis and Management 19(4):569-586.

Kahn, M. E. 2001. Does sprawl reduce the black/ white housing consumption gap? Housing Policy Debate 12(1):77-86.

Kim, C. H., and K. H. Kim. 2000. The political economy of Korean government policies on real estate. Urban Studies 37(7):1157-1169.

Kim, K. H. 1990. An analysis of inefficiency due to inadequate mortgage financing: the case of Seoul, Korea. Journal of Urban Economics 28(3):371-390.

Kim, K. H. 1993. Housing prices, affordability, and government policy in Korea. Journal of Real Estate Finance and Economics 6:55-71.

Kim, K. H., E. Mills, and B. N. Song. 1986. Korean government policies toward Seoul's greenbelt. Working Paper 86-2. Korea Research Institute for Human Settlements, Seoul, Republic of Korea.

Kim, S. B. 2004. The role of government in the redistribution of property rights: the case of the Korean greenbelt. International Review of Public Administration 9(1):97-111.

Knaap, G. J., and A. C. Nelson. 1988. The effects of regional land use control in Oregon: a theoretical and empirical review. The Review of Regional Studies 18:37-46.

Koh, K. S., M. H. Kim, J. H. Kim, K. D. Kil, J. H. Kim, J. S. Kim, and M. W. Lee. 1999.

Evaluation on the environment amelioration functions of green spaces in Chongju City by GIS. Korean Society for Environmental Impact Assessment 8(1):51-59.

Korea Times. 2003. Seoul City's short-sightedness: don't turn greenbelt into apartment complex. Editorial. 26 December 2003. [online] URL: http:// search.hankooki.com/times/times view.php?term= greenbelt++\&path=hankooki3/times/lpage/ opinion $/ 200312 / \mathrm{kt} 2003122619193011300 \cdot \mathrm{htm} \&$ media $=$ kt.

Kuhn, M. 2003. Greenbelt and green heart: separating and integrating landscapes in European city regions. Landscape and Urban Planning 64:19-27.

Kwon, J. A. 1995. Economic analysis of the greenbelt amenity in Seoul, Korea. Dissertation. Michigan State University, East Lansing, Michigan, USA.

Landis, J. D. 1995. Imaging land use futures: applying the California urban futures model. Journal of the American Planning Association 61 
(4):438-457.

Lee, C. M. 1999. An intertemporal efficiency test of a greenbelt: assessing the economic impacts of Seoul's greenbelt. Journal of Planning Education and Research 19(1):41-52.

Lee, S. C. 2004. Measuring public support for the Korean green belt policy: a multivariate analysis. Paper presented at the Association of Collegiate Schools of Planning 45th Annual Conference, Planning matters! People, places, and instiutions (21-24 October 2004), Portland, Oregon, USA.

Lee, C. M., and M. Fujita. 1997. Efficient configuration of a greenbelt: theoretical modeling of greenbelt amenity. Environment and Planning A 29(11):1999-2017.

Lee, C. M., and P. Linneman. 1998. Dynamics of the greenbelt amenity effect on the land market: the case of Seoul's greenbelt. Real Estate Economics 26(1):107-129.

Meier, R. L. 1970. Exploring development in great Asian cities: Seoul. Journal of the American Institute of Planners 36(6):378-392.

Millennium Ecosystem Assessment. 2005. Ecosystems and human well-being: synthesis. Island Press, Washington, D.C., USA. [online] URL: www.millenniumassessment.org/en/products. aspx.

Ministry of Construction and Transportation (MOCT). 1998. A survey for reform of the restricted development zone. MOCT, Seoul, Republic of Korea.

Mortberg, U., and H. Wallentinus. 2000. Redlisted forest bird species in an urban environment and assessment of green space corridors. Landscape and Urban Planning 50(4):215-226.

Munton, R. 1983. London's greenbelt: containment in practice. Allen and Unwin, London, UK.

Nelson, A. C. 1986. Using land markets to evaluate urban containment programs. Journal of the American Planning Association 52:156-170.

Nelson, A. C. 1988. An empirical note on how regional urban containment policy influences an interaction between greenbelt and exurban land markets. Journal of the American Planning Association 54:178-184.

Nelson, A. C. 1994. Oregon's urban growth boundary policy as a landmark planning tool. Pages 25-47 in C. Abbott, D. Howe, and S. Adler, editors. Planning the Oregon way: a twenty-year evaluation. Oregon State University Press, Corvallis, Oregon, USA.

Osborn, F. J. 1969. The green-belt principle: a note on its historical origins: Appendix I. Pages 167-180 in F. J. Osborn, editor. Green-belt cities. Schocken Books, New York, New York, USA.

Park, H. 2001. Environmentally friendly land use planning, property rights, and public participation in South Korea: a case study of greenbelt policy reform. Thesis. Virginia Polytechnic Institute and State University, Blacksburg, Virginia, USA. [online] URL: scholar.lib.vt.edu/theses/available/et d-05232001-172303/.

Park, J. C., and S. H. Lee. 2002. Village forests of Chinan. Chinan Cultural Unit, Seoul, Republic of Korea.

Pendall, R., J. Martin, and W. Fulton. 2002. Holding the line: urban containment in the United States. Center on Urban and Metropolitan Policy, The Brookings Institution, Washington, D.C., USA. [online] URL: http://www.brook.edu/dybdocroot/es/ urban/publications/pendallfultoncontainment.pdf.

Phillips, J., and E. Goodstein. 2000. Growth management and housing prices: the case of Portland, Oregon. Contemporary Economic Policy 18(3):334-344.

Pollack, P. 1998. Controlling sprawl in Boulder: benefits and pitfalls. Land Lines: Newsletter of the Lincoln Institute of Land Policy 10(1):1-3.

Poradek, J. 1997. Putting the use back in metropolitan land-use planning: private enforcement of urban sprawl control laws. Minnesota Law Review 81: 1343-1375.

Richardson, H. W., and C. Bae, editors. 2004. Urban sprawl in Western Europe and the United States. Ashgate, Burlington, Vermont, USA.

Son, J. Y., and K. H. Kim. 1998. Analysis of urban land shortages: the case of Korean cities. 
Journal of Urban Economics 43(3):362-384.

Song, B. N. 2003. The rise of the Korean economy. Third edition. Oxford University Press, New York, New York, USA.

Taylor, J., C. Paine, and J. Fitzgibbon. 1995.

From greenbelt to greenways: four Canadian case studies. Landscape and Urban Planning 33:47-64.

\section{Town and Country Planning Association.}

1999a. Commentary on RDZ policy reform in Korea, Volume 1: commentary on the draft report of the Committee on RDZ policy reform. Ministry of Construction and Transportation, Seoul, Republic of Korea.

\section{Town and Country Planning Association.} 1999b. Commentary on RDZ policy reform in Korea, Volume 2: implications for long term policy related to RDZ. Ministry of Construction and Transportation, Seoul, Republic of Korea.

United Nations Population Division, Department of Economic and Social Affairs (UNPD). 2002. World urbanization prospects: the 2001 revision. United Nations Publication Sales No. E.02.XIII.16. United Nations, New York, New York, USA. [online] URL: http://www.un.org/esa/population/pu blications/wup2001/WUP2001report.htm.

Wear, D. N., and J. G. Greis. 2002. Southern forest resource assessment: summary of findings. Journal of Forestry 100(7):6-14.

World Bank. 2004. World development indicators 2004. The World Bank, Washington, D.C., USA.

Yokohari, M., R. D. Brown, and K. Takeuchi. 1994. A framework for the conservation of rural ecological landscapes in the urban fringe area in Japan. Landscape and Urban Planning 29 (2-3):103-116.

Yokohari, M., R. D. Brown, Y. Kato, and H. Moriyama. 1997. Effects of paddy fields on summertime air and surface temperatures in urban fringe areas of Tokyo, Japan. Landscape and Urban Planning 38(1-2):1-11.

Yokohari, M., K. Takeuchi, T. Watanabe, and S. Yokota. 2000. Beyond greenbelts and zoning: a new planning concept for the environment of Asian mega-cities. Landscape and Urban Planning
47:159-171.

Zovanyi, G. 1998. Growth management for a sustainable future: ecological sustainability as the new growth management focus for the 21st century. Praeger, Westport Connecticut, USA. 